Article

\title{
Exogenous Potassium Treatments Elevate Salt Tolerance and Performances of Glycine max L. by Boosting Antioxidant Defense System under Actual Saline Field Conditions
}

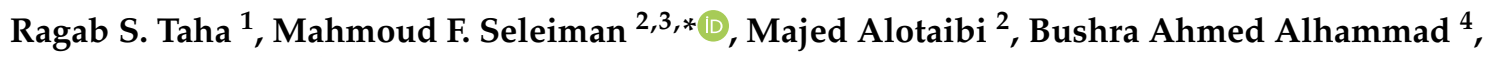 \\ Mostafa M. $\operatorname{Rady}^{5}\left(\mathbb{D}\right.$ and Ayman H. A. Mahdi ${ }^{6}$ \\ 1 Botany Department, Faculty of Agriculture, Beni Suef University, Beni Suef 62521, Egypt; \\ ragab.salama@agr.bsu.edu.eg \\ 2 Plant Production Department, College of Food and Agriculture Sciences, King Saud University, \\ P.O. Box 2460, Riyadh 11451, Saudi Arabia; malotaibia@ksu.edu.sa \\ 3 Department of Crop Sciences, Faculty of Agriculture, Menoufia University, Shibin El-kom 32514, Egypt \\ 4 Biology Department, College of Science and Humanity Studies, Prince Sattam Bin Abdulaziz University, \\ Al Kharj Box 292, Riyadh 11942, Saudi Arabia; b.alhammad@psau.edu.sa \\ 5 Botany Department, Faculty of Agriculture, Fayoum University, Fayoum 63514, Egypt; \\ mmr02@fayoum.edu.eg \\ 6 Agronomy Department, Faculty of Agriculture, Beni Suef University, Beni Suef 62521, Egypt; \\ drayman.hamdy@agr.bsu.edu.eg \\ * Correspondence: mseleiman@ksu.edu.sa; Tel.: +96-655-315-3351
}

Received: 26 October 2020; Accepted: 3 November 2020; Published: 9 November 2020

Abstract: Salinity is one of the major issues that limits field crop productivity in an arid and semiarid environment. Therefore, two field trials were carried out over two seasons of 2018 and 2019 to investigate the enhancement of different methods of potassium application (i.e., recommended soil amendment (control; $\mathrm{K}_{2} \mathrm{O}$ ), seed soaking (SS) and foliar spray (FS) in the form of potassium sulfate $\left.\left(\mathrm{K}_{2} \mathrm{SO}_{4}, 6 \mathrm{mM}\right)\right)$ on antioxidant protection, physio-biochemical, yield and quality traits of soybean (cv. Giza 22) grown in normal (electrical conductivity; $\mathrm{EC}=2.68 \mathrm{dS} \mathrm{m}^{-1}$ ) and saline soil $\left(\mathrm{EC}=7.46 \mathrm{dS} \mathrm{m}{ }^{-1}\right)$. Physio-biochemical attributes (total chlorophyll, carotenoids, $\mathrm{K}^{+}$and $\mathrm{K}^{+} / \mathrm{Na}^{+}$ ratios, performance index and catalase (CAT) activity), growth traits (i.e., shoot length, number and area of leaves plant ${ }^{-1}$ and shoot dry weight), yield and its components and seed quality (number of pods plant ${ }^{-1}, 100$-seed weight, seed yield ha ${ }^{-1}$ and seed protein and oil contents) were significantly decreased when soybean plants were grown in saline soil compared with those grown in normal soil. In contrast, activity of enzymatic antioxidants (i.e., superoxide dismutase (SOD), ascorbate peroxidase (APX) and glutathione peroxidase (GPX)), contents of non-enzymatic antioxidants and osmoprotectants (i.e., total soluble sugars, free proline, ascorbic acid and $\alpha$-tocopherol), $\mathrm{Na}^{+}, \mathrm{Cl}^{-}, \mathrm{H}_{2} \mathrm{O}_{2}$ and malondialdehyde (MDA) were increased in soybean plants grown in saline soil compared with normal soil. However, under salt-stressed conditions, potassium applied through SS or FS significantly enhanced all soybean growth, photosynthetic efficiency, $\mathrm{K}^{+}$content, ratio of $\mathrm{K}^{+} / \mathrm{Na}^{+}$and activity of CAT, SOD, APX and GPX as well as improved yield and quality traits, while potassium application did not affect the contents of non-enzymatic antioxidants and osmoprotectants. For instance, foliar potassium application (FS) increased seed yield $\mathrm{ha}^{-1}$ by $92.31 \%$ and protein content by $63.19 \%$ compared with the control under the salt stress condition. In addition, both applications of potassium significantly reduced $\mathrm{Na}^{+}, \mathrm{Cl}^{-}, \mathrm{H}_{2} \mathrm{O}_{2}$ and MDA contents in soybean plants compared with those obtained from control treatments. Exogenous application of $\mathrm{K}_{2} \mathrm{SO}_{4}$ was more effective than SS at improving soybean physio-biochemical attributes, yield and seed quality traits under soil-salinity stress. 
Keywords: soybean; salt stress; performance; physio-biochemical attributes; potassium; quality

\section{Introduction}

Soybean (Glycine max L.) is a legume grown for its seeds, which is considered valuable source of protein and oil for animal and human nutrition. Between $17 \%$ and $24 \%$ of the seed is composed of a highly palatable oil containing $29 \%$ sugars, $6 \%$ ash and zero cholesterol [1-3]. In addition, the seeds are rich in polyunsaturated fats, fiber, vitamins, energy and mineral nutrients [4]. Approximately $85 \%$ of the world's oil seeds are derived from soybeans, making it an important oil-seed crop. Soybeans are also used to produce biofuel [5]. The cultivation area and productivity of soybean are steadily increasing. For example, the world cultivated area and seed production were increased from $102.76 \mathrm{M}$ ha and 265.08 M t during 2010 to $124.92 \mathrm{M}$ ha and 348.62 $\mathrm{M}$ t during 2018, respectively [6].

Soil properties can be improved through soybean cultivation, which increases soil fertility by stabilizing soil nitrogen and enhances plant performance. Despite the importance of this crop, soybean agriculture faces a number of major challenges, such as climate change-related salinization of soils, particularly in arid and semi-arid zones. Salinity is a major factor that can affect plant life and represents a widespread stress conditions in many areas of the world, particularly dry regions $[7,8]$. Around $30 \%$ of the total agricultural cultivated lands are affected by salt stress, which poses a critical threat to the availability of cultivated lands, food and fodder. These lands suffer from poor growth and low plant productivity owing to the existence of soluble salts $[7,8]$. Salinity stress has many complicated influences and can induce changes in morpho-physiological, molecular, biochemical and ecological attributes $[1,7,9,10]$. It can passively influence growth, quantity and quality of crop yields [7]. Salt stress causes cellular membrane damage, which can lead to loss of ions. Consequently, relative water content can decrease under increased levels of a saline solution [11]. Salt stress results in the accumulation of reactive oxygen species (ROS), damaging numerous cell components, such as carbohydrates, nucleic acids, proteins and lipids [12], and degrading chlorophylls [13] due to cell lipid membrane [14]. However, plants' responses to salt stress are significantly differed, and practically most legume crops are considered sensitive to salinity $[9,11]$.

However, productivity of field crops, particularly soybean, can be significantly improved through the management of different environmental stresses, including soil salinity $[8,9,11]$. Potassium is an essential element that can increase plant dry matter and improve productivity [15-17]. It can be used to ameliorate salt stress toleration in plants $[15,16]$. Potassium contributes to root and leaf development, chlorophyll synthesis and stomata movement and reduces uptake and movement of toxic ions, such as $\mathrm{Na}^{+}$and $\mathrm{Cl}^{-}$. In addition, excessive ROS production can be controlled by potassium application, maintaining photoelectron transmission and mitigating the effects of nicotinamide adenine dinucleotide phosphate oxidase (NADPH) oxidase [18] on plants. Based on the above mentioned, application of potassium by appropriate methods on plants grown in salt soils can increase the efficiency of plant nutrition and improve the growth, physio-biochemical attributes, yield and quality of crops.

To mitigate salinity stress, using traditional or non-traditional methods application of plant nutrients can be one of the suitable options. Therefore, two field trials were carried out to investigate the enhancement of different methods of potassium application (i.e., recommended soil amendment (control; $\mathrm{K}_{2} \mathrm{O}$ ), seed soaking (SS) and foliar spray (FS) in the form of potassium sulfate $\left(\mathrm{K}_{2} \mathrm{SO}_{4}, 6 \mathrm{mM}\right)$ ) on antioxidant protection, physio-biochemical, yield and quality traits of soybean grown in actual normal $\left(E C=2.68 \mathrm{dS} \mathrm{m}^{-1}\right)$ and saline soil $\left(E C=7.46 \mathrm{dS} \mathrm{m}^{-1}\right)$. 


\section{Materials and Methods}

\subsection{Treatments, Design, and Plant Material of the Experiments}

Two field experiments were conducted in 2018 and 2019 at the Experimental Farm of Faculty of Agriculture, Fayoum University, Southeast Fayoum, Egypt, to investigate the effects of soil amendment (control), seed soaking (SS) and foliar spray (FS) of potassium on physio-biochemical, yield and quality traits of soybean grown in actual normal $\left(\mathrm{EC}=2.68 \mathrm{dS} \mathrm{m}^{-1} ; 29^{\circ} 19^{\prime} \mathrm{N} ; 30^{\circ} 51^{\prime} \mathrm{E}\right)$ and saline soil $\left(7.46 \mathrm{dS} \mathrm{m}^{-1} ; 29^{\circ} 17^{\prime} \mathrm{N} ; 30^{\circ} 53^{\prime} \mathrm{E}\right)$. For SS treatment, $2 \mathrm{~kg}$ of seeds was soaked in $4 \mathrm{~L}$ of $6 \mathrm{mM}$ potassium sulfate $\left(\mathrm{K}_{2} \mathrm{SO}_{4}\right)$ solution for $6 \mathrm{~h}$. For FS, plants were sprayed 3 times; at 20, 40 and 60 days after sowing (DAS) with $6 \mathrm{mM} \mathrm{K}_{2} \mathrm{SO}_{4}$. FS solutions were prepared with $0.1 \%$ Tween 20 added as a surfactant to ensure effective penetration. Meanwhile, the control treatment received the recommended potassium application (114 $\left.\mathrm{kg} \mathrm{K}_{2} \mathrm{O} \mathrm{ha}^{-1}\right)$ as a soil amendment both for normal and saline soil.

The experimental areas were divided into plots $5-\mathrm{m}$ long $\times 4.0-\mathrm{m}$ wide $\left(=20 \mathrm{~m}^{2}\right)$. The treatments were organized in randomized complete-blocks design with four replications. Soybean seeds (cv. Giza 22) were acquired from the Field Crop Research Institute, Giza, Egypt. Before sowing, the seeds of soybeans were sterilized in a solution of $\mathrm{HgCl}_{2}(0.1 \%)$ for $1 \mathrm{~min}$ and then washed several times in sterilized and deionized water. The physico-chemical properties of the experimental soils are presented in Table 1. The texture of the soil was clay in normal and saline soil. $\mathrm{pH}, \mathrm{EC}$ and organic matter were 7.45, $2.68 \mathrm{dS} \mathrm{m}^{-1}$ and $1.02 \%$ in normal soil and $7.62,7.46 \mathrm{dS} \mathrm{m}^{-1}$ and $0.86 \%$ in saline soil, respectively.

Table 1. Physico-chemical properties of the experimental soil.

\begin{tabular}{|c|c|c|c|c|c|c|c|c|c|c|c|}
\hline \multicolumn{4}{|c|}{ Particle Size Distribution } & \multirow{2}{*}{ FC } & \multirow[t]{2}{*}{$\mathrm{pH}$} & \multirow{2}{*}{$\mathrm{EC}_{\mathrm{e}} \mathrm{dS} \mathrm{m}^{-1}$} & \multirow{2}{*}{$\mathrm{CaCO}_{3} \%$} & \multirow{2}{*}{ OM \% } & \multicolumn{3}{|c|}{$\begin{array}{c}\text { Available } \\
\text { Macro-Nutrients (ppm) }\end{array}$} \\
\hline Sand $\%$ & Silt \% & Clay $\%$ & Texture class & & & & & & $\mathbf{N}$ & $\mathbf{P}$ & $\mathbf{K}$ \\
\hline \multicolumn{12}{|c|}{ Normal soil (Location 1) } \\
\hline 25.9 & 27.0 & 47.1 & Clay & 29.2 & 7.45 & 2.68 & 3.98 & 1.02 & 242 & 4.26 & 266 \\
\hline \multicolumn{12}{|c|}{ Saline soil (Location 2) } \\
\hline 28.7 & 29.3 & 42.0 & Clay & 27.2 & 7.62 & 7.46 & 3.45 & 0.86 & 198 & 1.92 & 162 \\
\hline
\end{tabular}

$\mathrm{FC}=$ Field capacity of soil; $\mathrm{OM}=$ Organic matter.

The seeds were sown on 1 June 2018 and 3 June 2019. Seeds were drilled into one split side of ridges at $95 \mathrm{~kg} \mathrm{ha}^{-1}$. The thinning process for plants was conducted immediately before the first irrigation to ensure one seedling at every $5 \mathrm{~cm}$. Fertilization with nitrogen at $48 \mathrm{~kg} \mathrm{~N} \mathrm{ha}^{-1}$ and phosphorus at $74 \mathrm{~kg} \mathrm{P}_{2} \mathrm{O}_{5} \mathrm{ha}^{-1}$ was applied as recommended. The plants were irrigated by $100 \%$ of the reference crop evapotranspiration (ETo), values at the Fayoum Meteo Station, Egypt.

\subsection{Measurements}

Growth characteristics, physio-biochemical attributes and antioxidant defense systems of soybean plant samples collected at 70 DAS were analyzed as follows.

\subsubsection{Growth Traits and Photosynthesis Pigment Analyses}

Soybean samples were collected at 70 DAS by harvesting 9 plants randomly from each plot to measure shoot length (using ruler), leaf number and area of laves plant ${ }^{-1}$ (Portable Leaf Area Meter, LI-3000C, LI-COR Inc., WA, USA). The samples were oven-dried for $72 \mathrm{~h}$ or until a constant weight was reached at $65^{\circ} \mathrm{C}$ and dry weights were then recorded.

The third fresh leaf of 9 plants was randomly chosen from each plot, frozen in liquid nitrogen, ground and stored at $25{ }^{\circ} \mathrm{C}$ until further analysis. Leaf chlorophyll and carotenoid contents were measured with acetone extract using a spectrophotometer (UV-160A, Shimadzu, Japan) at 663, 645 and $470 \mathrm{~nm}$ [19]. Photosynthetic performance index was calculated as described by Clark et al. [20]. 


\subsubsection{Extraction and Determination of Inorganic Solutes}

To prepare the extracts, freeze-dried soybean leaf powder $(50 \mathrm{mg})$ was incubated in $5 \mathrm{~mL}$ of deionized water for $1 \mathrm{~h}$ in a $45^{\circ} \mathrm{C}$ water bath and then centrifuged for $10 \mathrm{~min}$ at $3000 \mathrm{~g}$ and $25^{\circ} \mathrm{C}$. This was followed by filtrating of the supernatant, which was stored at $25^{\circ} \mathrm{C}$ until the measurements. Using flame photometry, $\mathrm{Na}^{+}$and $\mathrm{K}^{+}$levels were estimated [21]. $\mathrm{Cl}^{-}$content was determined by spectrophotometry following described method by Gaines et al. [22].

\subsubsection{Determination of Osmoprotectants and Non-Enzymatic Antioxidant Contents}

Free proline was measured following a method described in Sofy et al. [23]. A 0.5-g sample of dried soybean leaves was ground in sulfosalicylic acid (3\%) and centrifuged at 10,000 $\mathrm{g}$ for $10 \mathrm{~min}$. The supernatants were mixed with ninhydrin $(2 \%)$ and glacial acetic acid, heated at $90{ }^{\circ} \mathrm{C}$ for $30 \mathrm{~min}$ and then allowed to cool. Next, toluene was added to the previous admixture. Readings were taken spectrophotometrically at $520 \mathrm{~nm}$.

To determine the total soluble sugars (TSS), an alcohol extract was prepared as described by Irigoyen et al. [24] and $3 \mathrm{~mL}$ of anthrone reagent (150 mg of anthrone in $100 \mathrm{~mL}$ of $72 \%$ sulphuric acid) was added to $0.1 \mathrm{~mL}$ of the alcohol extract, which was boiled for $10 \mathrm{~min}$ and then allowed to cool. Spectrophotometric readings were taken at $625 \mathrm{~nm}$.

Ascorbic acid (AsA) was measured as described by Mukherjee and Choudhuri [25]. A $2 \mathrm{~mL}$ sample of $2 \%$ dinitrophenylhydrazine was added to the samples extracted in $6 \%$ trichloroacetic acid (TCA). Next, a single drop of thiourea (10\%) in ethanol (70\%) was added to the mixture, which was immersed in a boiling water bath for $15 \mathrm{~min}$. The mixture was left to cool and then five $\mathrm{mL}$ of $\mathrm{H}_{2} \mathrm{SO}_{4}$ $(80 \%)$ at $0{ }^{\circ} \mathrm{C}$ and absorbance was read using a spectrophotometer at $530 \mathrm{~nm}$.

The glutathione (GSH) content in fresh soybean leaf tissue was estimated using a method described by Griffith [26]. Fresh soybean leaf tissue was ground in meta-phosphoric acid (2\%) and then centrifuged for homogenized for $10 \mathrm{~min}$ at $17,000 \mathrm{~g}$. Sodium citrate was used to neutralize supernatants and each assay, including a solution formed of $700 \mu \mathrm{L}$ of $0.3 \mathrm{mM} \mathrm{NADPH}, 100 \mu \mathrm{L}$ distilled water and

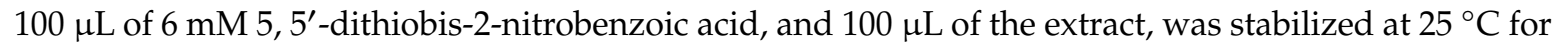

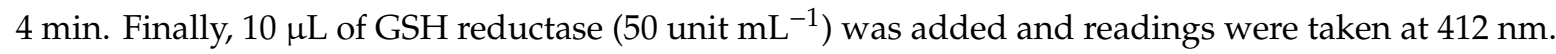

A method described by Konings et al. [27] was used to measured $\alpha$-tocopherol ( $\alpha$-TOC) content and R-TOC was used as a standard solution. A Waters Bondapak C18 reverse-phase column was used to measure the $\alpha$-TOC on a high-performance liquid chromatography system. A mobile phase of methanol/water (94:6) was used at a flow rate of $1.5 \mathrm{~mL} \mathrm{~min}^{-1}$ and an ultraviolet detector was set to $292 \mathrm{~nm}[28]$.

\subsubsection{Determination of Malondialdehyde and Hydrogen Peroxide Contents}

By assessing malondialdehyde (MDA) content, lipid peroxidation levels were measured as explained in [29] and MDA was estimated using a 2-thiobarbituric acid reaction. A fresh 1-g leaf sample was mixed with $1 \mathrm{~mL}$ of $10 \%$ TCA and $1 \mathrm{~mL}$ of $0.67 \%$ thiobarbituric acid and then heated in a boiling water bath for $15 \mathrm{~min}$. MDA was estimated using spectrophotometer with absorbance measured at $535 \mathrm{~nm}$ and expressed as $\mu \mathrm{mol} \mathrm{g}^{-1}$ (FW) of MDA.

The $\mathrm{H}_{2} \mathrm{O}_{2}$ content was measured following described method by Mukherjee and Choudhuri [25] with a simple change by the ice-cold acetone extract of a $2 \mathrm{~mL}$ soybean sample mixed with a titanium reagent and $\mathrm{NH}_{4} \mathrm{OH}(0.4 \mathrm{~mL})$ to produce a complex of hydroperoxide-titanium, which was centrifuged for $10 \mathrm{~min}$ at $12,000 \mathrm{~g}$. The precipitate was dissolved in $2 \mathrm{~mL}$ of $2 \mathrm{M} \mathrm{H}_{2} \mathrm{SO}_{4}$ and absorbance was measured by spectrophotometer at $415 \mathrm{~nm}$ against a blank reagent. The $\mathrm{H}_{2} \mathrm{O}_{2}$ content $\left(\mu \mathrm{mol} \mathrm{g}{ }^{-1} \mathrm{FW}\right.$ ) was measured using a known concentration of $\mathrm{H}_{2} \mathrm{O}_{2}$ to plot a standard curve. 


\subsubsection{Antioxidant Enzymes}

To make extracts of enzymes, $200 \mathrm{mg}$ of freeze-dried powder of soybean leaves was homogenized in a cold mortar with $2 \mathrm{~mL}$ of a $100 \mathrm{mM}$ potassium phosphate buffer at $\mathrm{pH} 7.0$, including Ethylenediaminetetraacetic acid; EDTA $(0.1 \mathrm{mM})$.

To measure ascorbate peroxidase (APX) activity, AsA ( $2 \mathrm{mM})$ was mixed with the extraction buffer, filtered and centrifuged for $15 \mathrm{~min}$ at $12,000 \mathrm{~g}$. All processes were carried out at $4{ }^{\circ} \mathrm{C}$ and the extract was stored at $-25^{\circ} \mathrm{C}$ until analyzed. The content of protein in the extracts was evaluated following a method described by Bradford [30].

A method detailed by Beauchamp and Fridovich [31] was used to detect superoxide dismutase (SOD) activity (EC 1.15.1.1) by defining its ability to dampen the reduction of photochemical of nitro blue tetrazolium (NBT) chloride. The amount of enzyme causing a 50\% damping of the rate of NBT photoreduction was described as 1 unit of activity of SOD and the results were measured in $\mathrm{U} / \mathrm{mg}$ protein.

The activity of catalase (CAT) (EC 1.11.1.6) was measured as described by Harvir and MacHale [32] by observing the absorbance decrease at $240 \mathrm{~nm}$ due to the breakdown of $\mathrm{H}_{2} \mathrm{O}_{2}(\varepsilon=36 / \mathrm{M} / \mathrm{cm})$. Nakano and Asada's [33] method was used to estimate APX activity (1.11.1.11) by observing the AsA oxidation, which was evaluated as the absorbance decrease at $290 \mathrm{~nm}\left(\varepsilon=2.8 \times 10^{-3} / \mathrm{M} / \mathrm{cm}\right)$.

Kar and Mishra [34] developed a method to evaluate the activity of glutathione peroxidase (GPX) (EC 1.11.1.9) by observing the absorbance increment at $470 \mathrm{~nm}$ because of the production of tetraguaiacol $\left(\varepsilon=26.6 \times 10^{-3} / \mathrm{M} / \mathrm{cm}\right)$. Activities of CAT, GPX and APX were measured in $\mu \mathrm{mol}$ of $\mathrm{H}_{2} \mathrm{O}_{2} / \mathrm{min} / \mathrm{mg}$ protein (DW).

\subsubsection{Determination of Yield Attributes and Seed Quality}

At the end of each experiment, the soybean plants of each experimental unit (i.e., plot) were harvested. Ten plants were used for counting the number of pods per plants. Dry soybean seeds were separated from their pods to record 100-seed weight and seed soybean yield ha ${ }^{-1}$. Seed protein and oil contents were analyzed as described in [35] methods. A part of seed quality analysis was done at King Saud University.

\subsection{Statistical Analysis}

Data obtained from the effects of different treatments (control, SS and FS) on physio-biochemical, yield and quality traits of soybean grown in normal and saline soil were subjected to analysis of variance (ANOVA) using PASW statistics 21.0 (IBM Inc., Chicago, IL, USA). The homogeneity test of error variance was conducted as stated in a method described by Gomez and Gomez [36]. Data from the two seasons were subjected to a combined analysis and Duncan's range test was used to compare significant differences between treatments at a significance level of $p \leq 0.05$.

\section{Results}

Under saline conditions ( $\left.7.46 \mathrm{dS} \mathrm{m}^{-1} ; 4774 \mathrm{ppm}\right)$, all growth characteristics of soybean plants were significantly lower than those of plants grown in normal soil (Figure 1). However, potassium applied by FS or SS markedly increased growth traits compared with the control (Figure 1). Under normal conditions, potassium applied by FS significantly increased some of the investigated soybean growth characteristics, such as leaf number plant $^{-1}$ and dry weight of shoots, while not affecting others (i.e., length of shoot and area of leaves plant ${ }^{-1}$ ) compared with controls (potassium soil addition) (Figure 1). However, potassium applied through SS did not affect any of the tested growth characteristics. Potassium applied by FS showed superior results compared with SS, increasing shoot length by $39.9 \%$, leaf number plant ${ }^{-1}$ by $51.9 \%$, area of leaves plant ${ }^{-1}$ by $73.6 \%$ and dry weight of shoots by $56.4 \%$ compared with the control (Figure 1 ). 


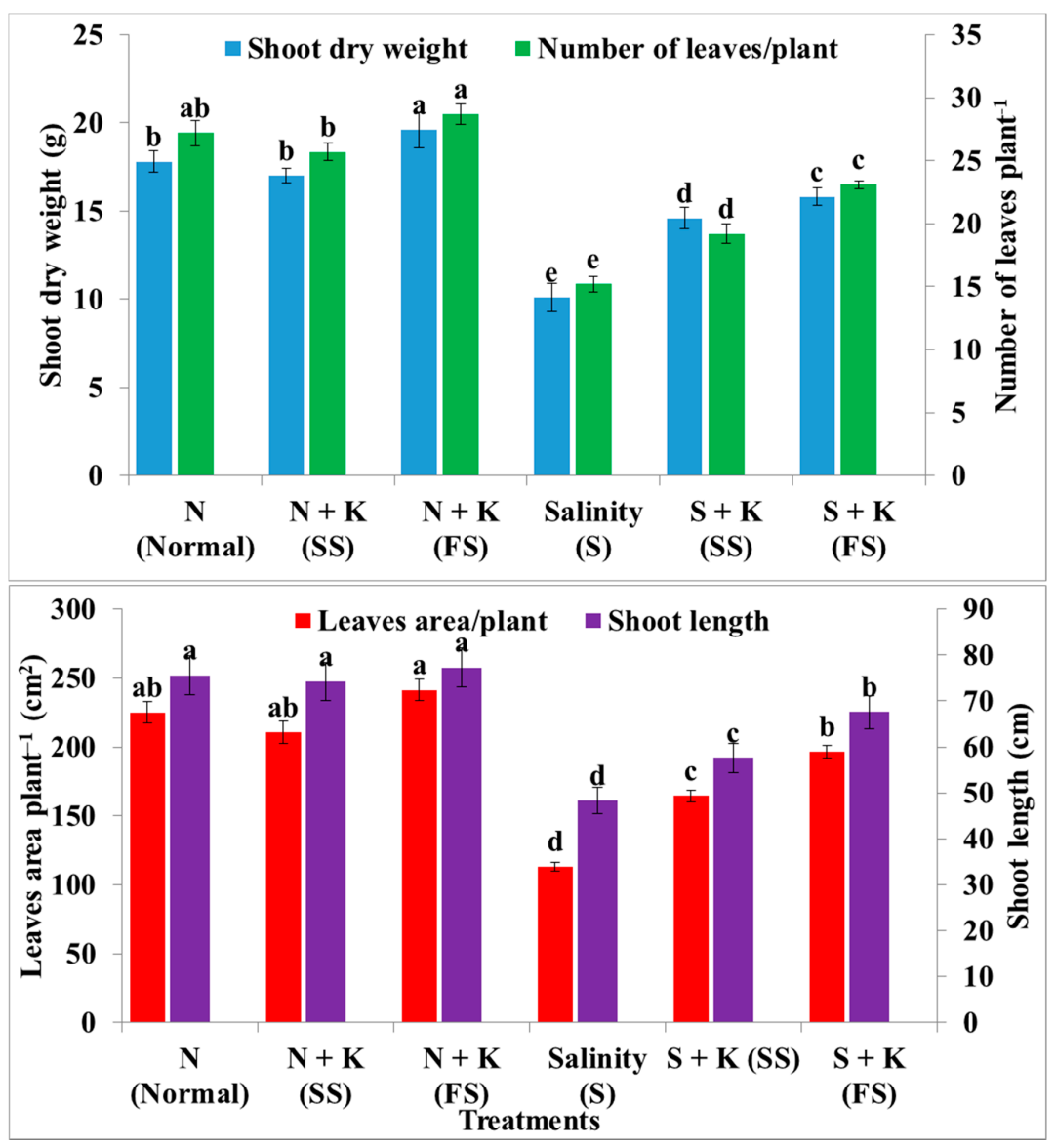

Figure 1. Effect of seed soaking (SS) and foliar spray (FS) of potassium $\left(6 \mathrm{mM} \mathrm{K}_{2} \mathrm{SO}_{4}\right)$ on growth traits of soybean plants grown under normal $\left(\mathrm{EC}=2.68 \mathrm{dS} \mathrm{m}^{-1}\right)$ and salt stress $\left(\mathrm{EC}=7.46 \mathrm{dS} \mathrm{m}^{-1}\right)$ conditions . Means followed by the same letter in each parameter are not significantly different according to the least significant differences (LSD) test $(p \leq 0.05)$. Error bars are \pm Standard Error (SE).

Except for a significant increase in total chlorophyll content by FS of potassium, total chlorophylls, total carotenoid contents and performance index (PI, \%) were not affected by potassium applied as SS or FS to normal soil compared to the control (Figure 2). Under a salinity level of $7.46 \mathrm{dS} \mathrm{m}^{-1}$, total chlorophylls, carotenoids contents and the PI\% were significantly decreased compared with the control. Nevertheless, FS or SS with potassium significantly increased these photosynthetic parameters, with a preference for FS, compared with the control (Figure 2). FS with potassium was the most effective treatment, increasing the total chlorophyll content by $184.5 \%$, total carotenoids by $20 \%$ and the PI by $43.8 \%$ compared with the control. Under salt stress, the impact of potassium on soybean photosynthetic parameters was evident compared with normal conditions.

At $2.68 \mathrm{ds} \mathrm{m}^{-1}$ salinity, FS with potassium was found to exceed SS and increased $\mathrm{K}^{+}$content and the ratio of $\mathrm{K}^{+} / \mathrm{Na}^{+}$while decreasing $\mathrm{Na}^{+}$and $\mathrm{Cl}^{-}$contents compared with the control (Figure 3). Salt treatment significantly reduced $\mathrm{K}^{+}$content and the $\mathrm{K}^{+} / \mathrm{Na}^{+}$ratio and significantly increased $\mathrm{Na}^{+}$ and $\mathrm{Cl}^{-}$contents compared with the normal control (Figure 3). Compared with the corresponding control, potassium applied as an FS or SS markedly increased the content of $\mathrm{K}^{+}$and the ratio of $\mathrm{K}^{+} / \mathrm{Na}^{+}$ but significantly decreased the contents of $\mathrm{Na}^{+}$and $\mathrm{Cl}^{-}$under salt stress. FS with potassium was the most effective treatment, increasing the content of $\mathrm{K}^{+}$by $47.18 \%$ and the ratio of $\mathrm{K}^{+} / \mathrm{Na}^{+}$by $361.29 \%$ and reducing $\mathrm{Na}^{+}$by $68.53 \%$ and $\mathrm{Cl}^{-}$by $58.82 \%$ compared with the control (Figure 3). 


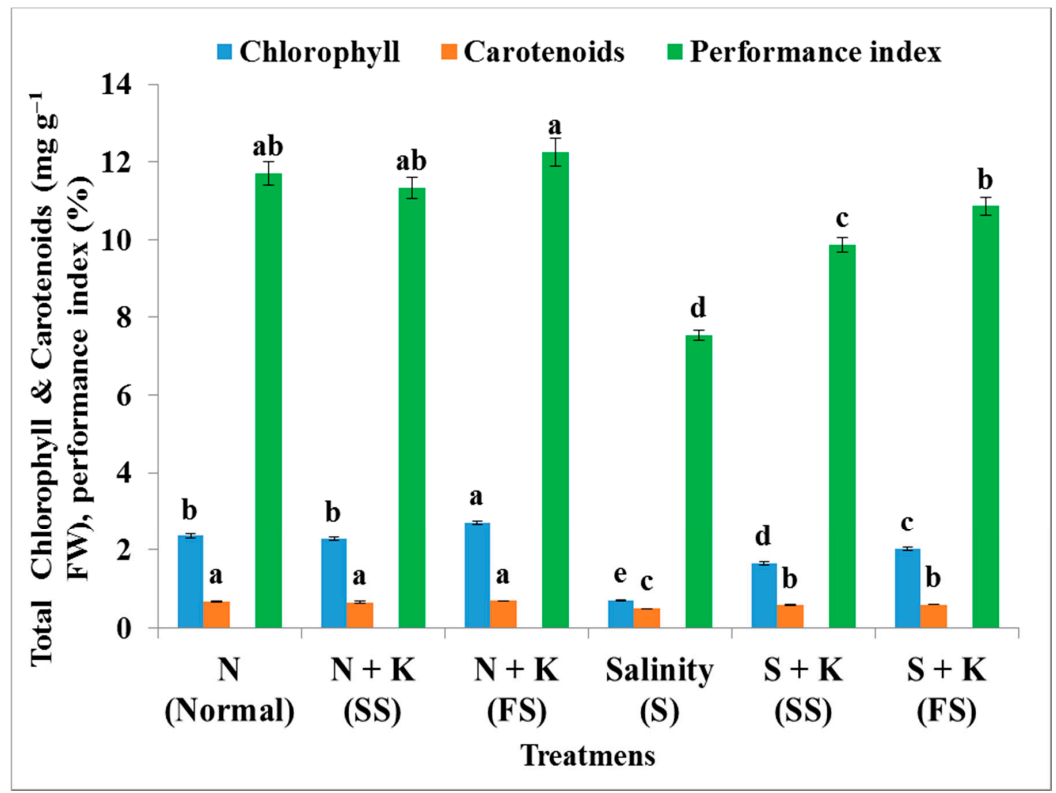

Figure 2. Effect of seed soaking (SS) and foliar spray (FS) of potassium $\left(6 \mathrm{mM} \mathrm{K}_{2} \mathrm{SO}_{4}\right)$ on photosynthetic pigments and their efficiency (performance index; PI) of soybean plants grown under normal $\left(E C=2.68 \mathrm{dS} \mathrm{m}^{-1}\right)$ and salt stress $\left(E C=7.46 \mathrm{dS} \mathrm{m}^{-1}\right)$ conditions. Means followed by the same letter in each parameter are not significantly different according to the LSD test $(p \leq 0.05)$. Error bars are \pm Standard Error (SE).

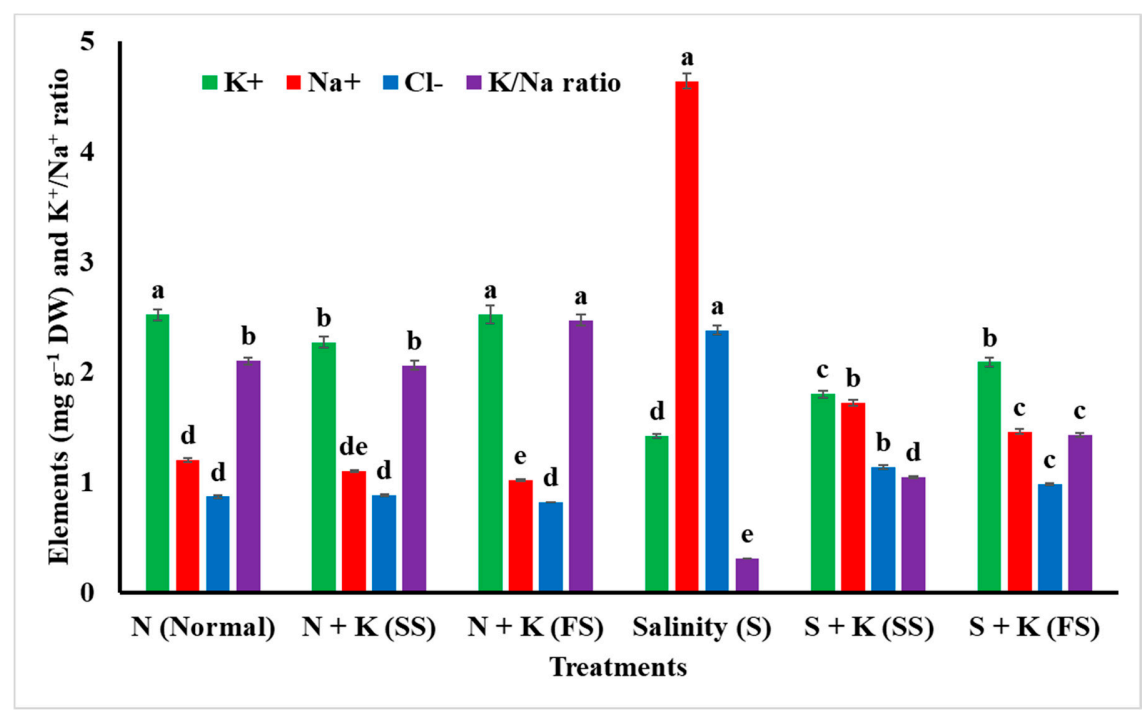

Figure 3. Effect of seed soaking (SS) and foliar spray (FS) of potassium $\left(6 \mathrm{mM} \mathrm{K}_{2} \mathrm{SO}_{4}\right)$ on potassium $\left(\mathrm{K}^{+}\right)$, Sodium $\left(\mathrm{Na}^{+}\right)$and Chloride $\left(\mathrm{Cl}^{-}\right)$contents, and $\mathrm{Na}^{+} / \mathrm{K}^{+}$ratio of soybean plants grown under normal $\left(\mathrm{EC}=2.68 \mathrm{dS} \mathrm{m}^{-1}\right)$ and salt stress $\left(\mathrm{EC}=7.46 \mathrm{dS} \mathrm{m}^{-1}\right)$ conditions. Means followed by the same letter in each parameter are not significantly different according to the LSD test $(p \leq 0.05)$. Error bars are \pm Standard Error (SE).

Under normal conditions, potassium applied by FS or SS did not significantly affect the contents of TSS, free proline, AsA, GSH, $\alpha$-tocopherol, MDA and $\mathrm{H}_{2} \mathrm{O}_{2}$, and the activities of SOD, APX, CAT and GPX, compared with the control (Figures 4-6). On the other hand, all the aforementioned traits were markedly increased in soybean plants grown under salt stress compared with the normal control. However, potassium applied as FS or SS further increased the contents of TSS, free proline, AsA, GSH and $\alpha$-TOC and the activities of CAT, SOD, APX and GPX, while significantly reducing MDA 
and $\mathrm{H}_{2} \mathrm{O}_{2}$ contents compared with the salinized control. Potassium applied by FS showed superior results compared with potassium applied by SS. This superior treatment increased the content of TSS by $19.33 \%$, free proline by $0.41 \%$, AsA by $14.79 \%$, GSH by $21.81 \%$ and $\alpha$-TOC by $23.53 \%$ and activity of SOD by $21.87 \%$, CAT by $143.07 \%$, APX by $17.16 \%$ and GPX by $13.82 \%$, while decreasing MDA content by $49.47 \%$ and $\mathrm{H}_{2} \mathrm{O}_{2}$ content by $56.99 \%$, compared with the control (Figures 4-6).

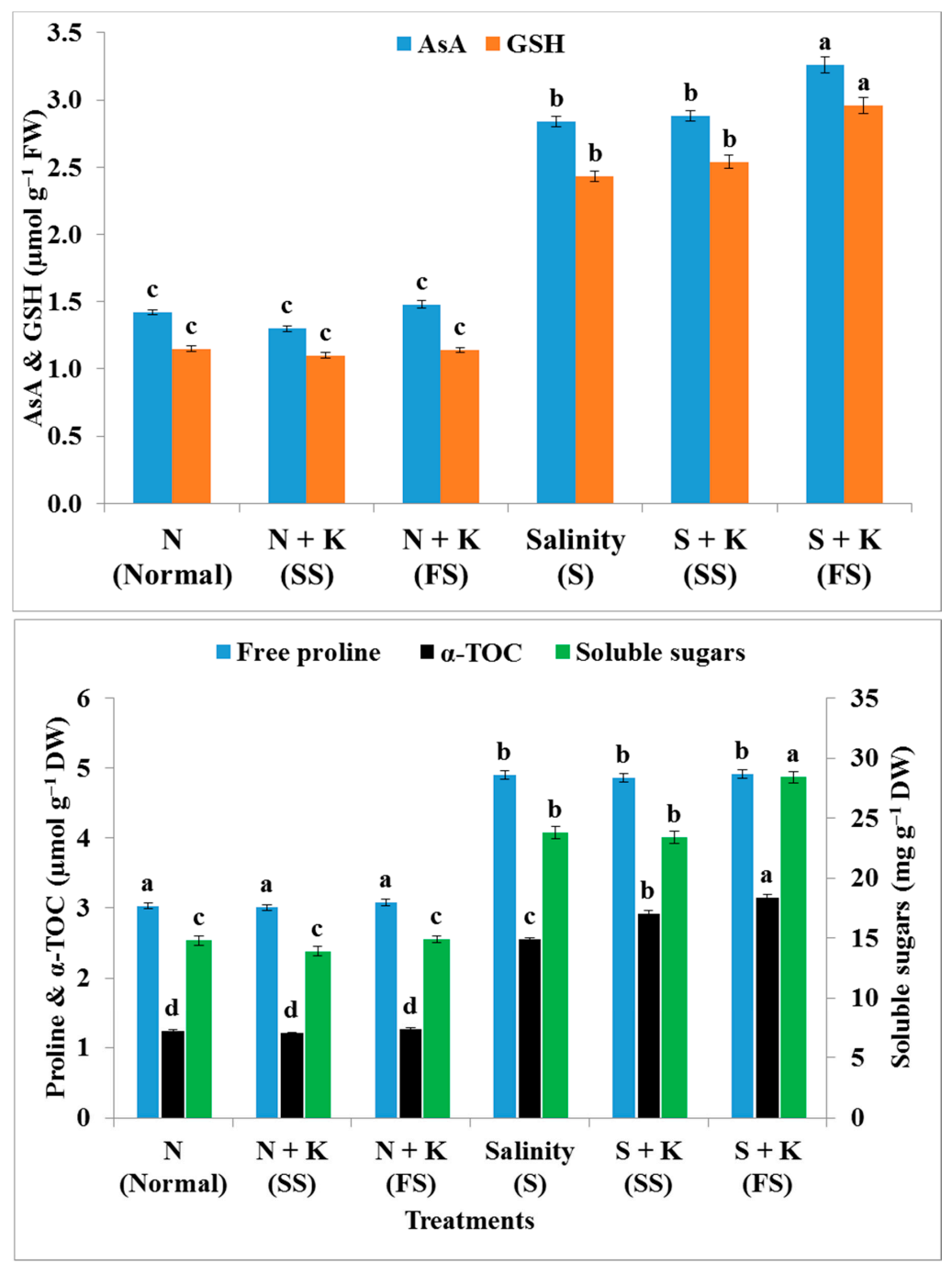

Figure 4. Effect of seed soaking (SS) and foliar spray (FS) of potassium (6 $\left.\mathrm{mM} \mathrm{K}_{2} \mathrm{SO}_{4}\right)$ on free proline, total soluble sugars, ascorbic acid (AsA), glutathione (GSH) and $\alpha$-tocopherol ( $\alpha$-TOC) contents of soybean plants grown under normal $\left(\mathrm{EC}=2.68 \mathrm{dS} \mathrm{m}^{-1}\right)$ and salt stress $\left(\mathrm{EC}=7.46 \mathrm{dS} \mathrm{m}^{-1}\right)$ conditions. Means followed by the same letter in each parameter are not significantly different according to the LSD test $(p \leq 0.05)$. Error bars are \pm Standard Error (SE).

As shown in Figures 7 and 8, with the exception of limited fluctuation, FS or SS with potassium did not affect soybean yield or its components and quality (pods number plant ${ }^{-1}, 100$-seed weight, yield of seed ha ${ }^{-1}$, protein $\%$ and oil \%) under normal conditions compared with controls. However, salt-stress treatment markedly reduced these yield parameters compared with the normal control (Figure 7). Compared with the corresponding control, potassium applied by FS or SS significantly increased the pod number plant ${ }^{-1}, 100$-seed weight, yield of seed $\mathrm{ha}^{-1}$, protein $\%$ and oil $\%$ under salt stress. FS of potassium increased pod numbers plant ${ }^{-1}$ by $109.72 \%, 100$-seed weight by $133.33 \%$, seed yield ha ${ }^{-1}$ by $92.31 \%$, protein content by $63.19 \%$ and oil content by $59.15 \%$, compared with the control (Figures 7 and 8). 


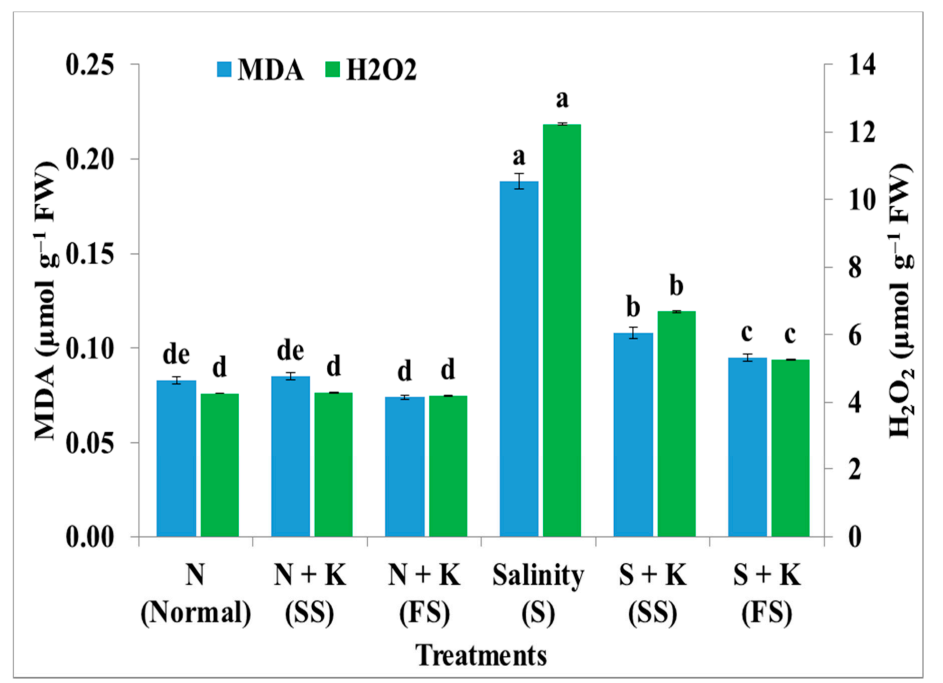

Figure 5. Effect of seed soaking (SS) and foliar spray (FS) of potassium (6 $\left.\mathrm{mM} \mathrm{K}_{2} \mathrm{SO}_{4}\right)$ on lipid peroxidation (measured as malondialdehyde (MDA) content) and hydrogen peroxide $\left(\mathrm{H}_{2} \mathrm{O}_{2}\right)$ content of soybean plants grown under normal $\left(\mathrm{EC}=2.68 \mathrm{dS} \mathrm{m}^{-1}\right)$ and salt stress $\left(\mathrm{EC}=7.46 \mathrm{dS} \mathrm{m}^{-1}\right)$ conditions. Means followed by the same letter in each parameter are not significantly different according to the LSD test $(p \leq 0.05)$. Error bars are \pm Standard Error $(\mathrm{SE})$.

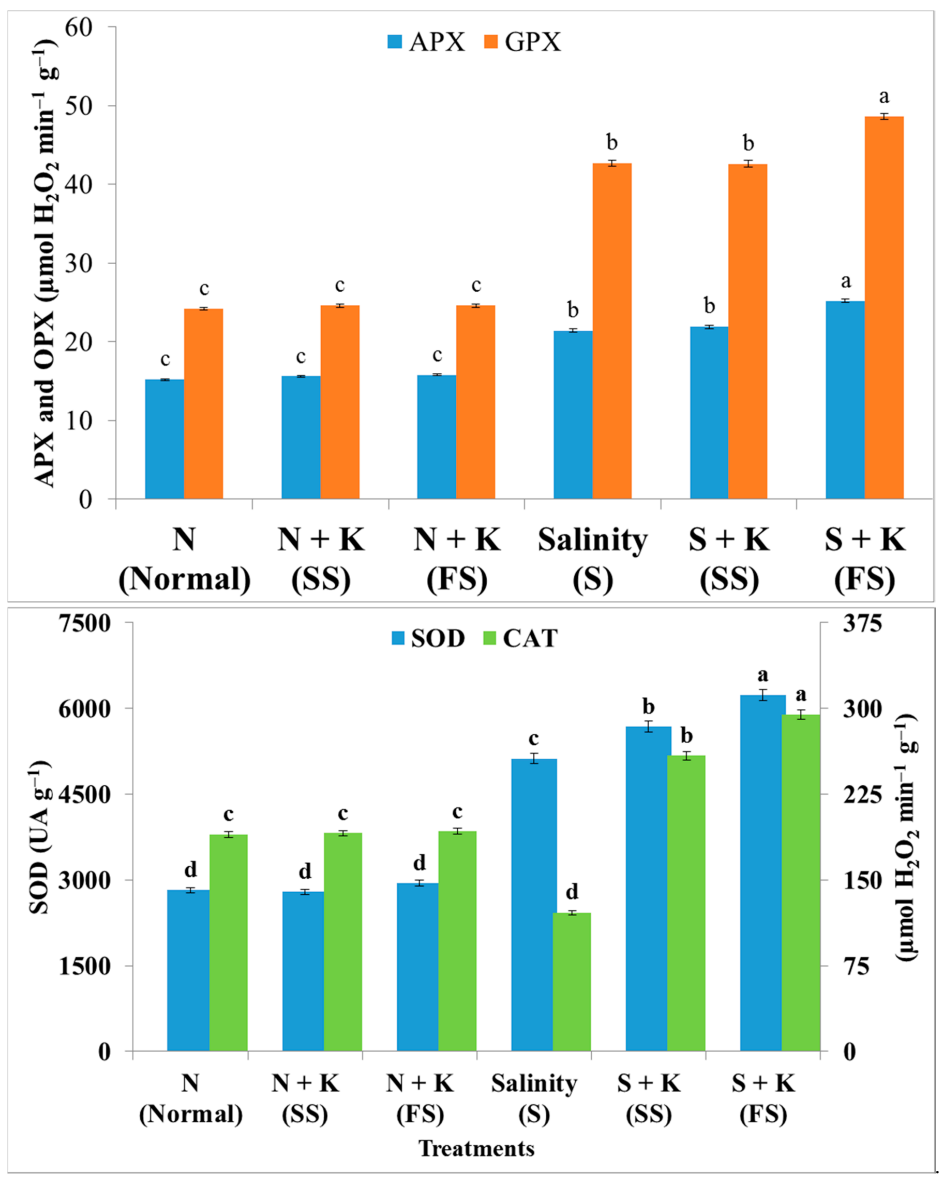

Figure 6. Effect of seed soaking (SS) and foliar spray (FS) of potassium (6 $\left.\mathrm{mM} \mathrm{K}_{2} \mathrm{SO}_{4}\right)$ on leaf activities of superoxide dismutase ascorbate peroxidase (APX), glutathione peroxidase (GPX), superoxide dismutase (SOD) and catalase (CAT) in soybean plants grown under normal $\left(\mathrm{EC}=2.68 \mathrm{dS} \mathrm{m}^{-1}\right)$ and saline $\left(\mathrm{EC}=7.46 \mathrm{dS} \mathrm{m}^{-1}\right)$ conditions. Means followed by the same letter in each parameter are not significantly different according to the LSD test $(p \leq 0.05)$. Error bars are \pm Standard Error (SE). 


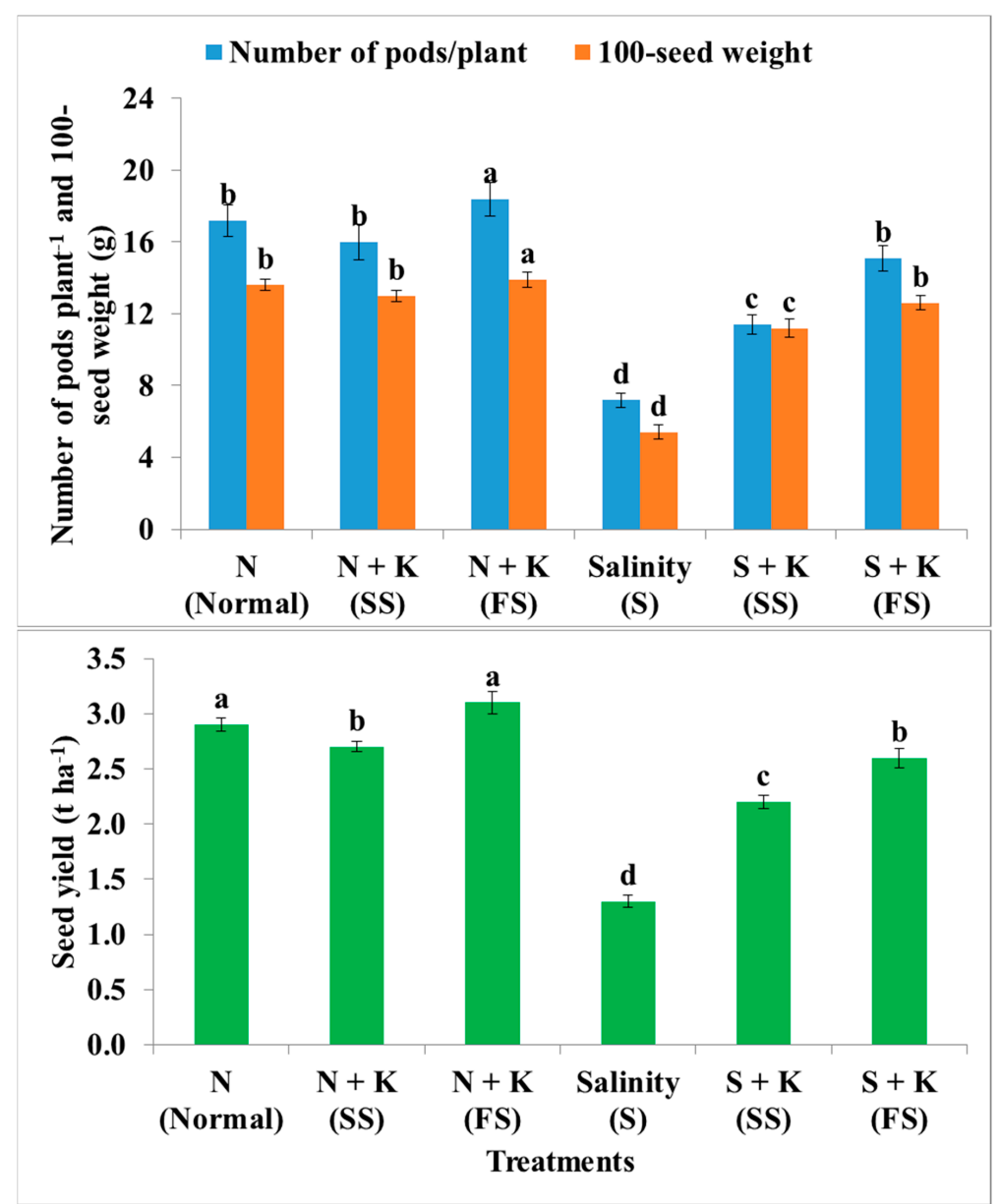

Figure 7. Effect of seed soaking (SS) and foliar spray (FS) of potassium $\left(6 \mathrm{mM} \mathrm{K}_{2} \mathrm{SO}_{4}\right)$ on yield attributes of soybean plants grown under normal $\left(E C=2.68 \mathrm{dS} \mathrm{m}^{-1}\right)$ and saline $\left(E C=7.46 \mathrm{dS} \mathrm{m}^{-1}\right)$ conditions. Means followed by the same letter in each parameter are not significantly different according to the LSD test $(p \leq 0.05)$. Error bars are \pm Standard Error (SE).

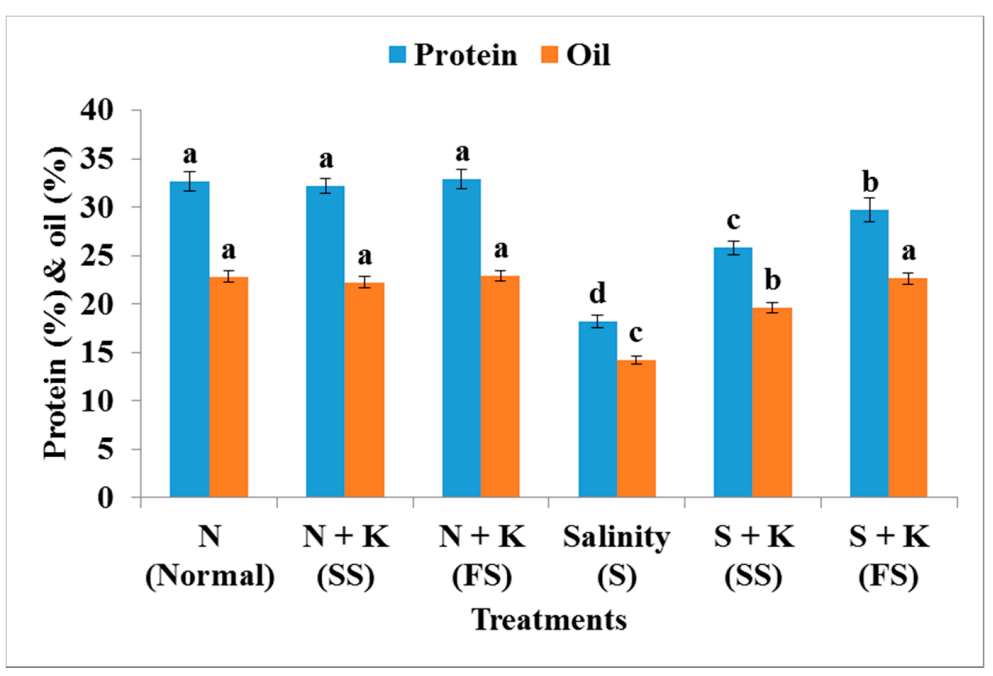

Figure 8. Effect of seed soaking (SS) and foliar spray (FS) of potassium ( $\left.6 \mathrm{mM} \mathrm{K}_{2} \mathrm{SO}_{4}\right)$ on seed quality of soybean plants grown under normal $\left(E C=2.68 \mathrm{dS} \mathrm{m}^{-1}\right)$ and saline $\left(\mathrm{EC}=7.46 \mathrm{dS} \mathrm{m}^{-1}\right)$ conditions. Means followed by the same letter in each parameter are not significantly different according to the LSD test $(p \leq 0.05)$. Error bars are \pm Standard Error (SE). 


\section{Discussion}

Among various abiotic stresses, salinity is recognized as a complex and devastating factor because of its negative multidimensional nature and the potential harm to plants $[7,8,10,11,16,37-39]$. Salinity has different harmful influences on plant performance, limiting its production $[7,8,40]$. Salinity stress causes water shortages that negatively affect chlorophyll content, chloroplast ultrastructure and the photosynthetic apparatus, which can lead to cell death [41,42]. Salinity stress also stimulates the accumulation of ROS, such as $\mathrm{O}_{2}{ }^{\bullet-}, \mathrm{OH}^{-}, \mathrm{H}_{2} \mathrm{O}_{2}$ and ${ }^{1} \mathrm{O}_{2}$, which harm plant tissues due to oxidization of macromolecules (i.e., lipids and proteins) [43-45].

In the current work, defects in the growth of soybean plants or yields under saline soil conditions (Figures 1,2 and 7) may be due to osmotic impacts of salt stress or increments in growth retardants, suppression of growth promoters and water imbalance. The restrained influences of salinity are expressed as stomatal closing, ionic disturbance, decreases in photosynthesis and harmful ions levels, resulting in reduction in growth $[10,39,46]$. SS or FS of soybean plants with potassium significantly improved the growth parameters and yield of soybean plants, as well as their physio-biochemical traits under normal and saline soil conditions. The results of this study show that the maximum increase in data obtained was achieved using potassium applied by FS on soybean plants grown in normal soil $\left(2.68 \mathrm{dS} \mathrm{m}^{-1}\right)$. These outcomes are similar to those outlined previously by Hernandez et al. [47]. They attributed the superior results to the fact that potassium is required for different bio-internal and physiological processes associated with plant growth and development.

Potassium plays a role in carbohydrate metabolism, synthesis of protein and activation of enzymes [48]. It helps balance cations and anions and enables movement of water, transfer of energy, regulation of osmotic and many other processes. The FS approach was more efficient than SS due to the capacity for absorption by fast penetration into leaves, compensating for scanty uptake by roots. However, efficient foliar application requires sufficient leaf area [49]. Under conditions of salt-stressed soil $\left(7.46 \mathrm{dS} \mathrm{m}^{-1}\right)$, the application of potassium resulted in an increase in total chlorophylls, carotenoids and PI values (Figure 2). The magnitude of increase was more pronounced with FS (Figure 2). Potassium is an essential element that plays an important role in maintaining and enhancing a plant's photosynthetic apparatus [50,51]. This is likely due to the role of potassium in increasing leaf number and area, accelerating the photosynthetic rate per leaf area unit [50]. In addition, potassium regulates the stomatal apparatus by balancing $\mathrm{CO}_{2}$ entry and $\mathrm{H}_{2} \mathrm{O}$ vapor elimination from intercalary spaces [52]. It also stimulates ATPase synthesis, facilitating the photosynthesis process. Shingles and McCarty [53] reported that the performance of ATPase is best when potassium levels are optimal.

Under salinity stress, the osmotic action and toxicity of ions (i.e., $\mathrm{Na}^{+}$and $\mathrm{Cl}^{-}$) inhibit plant root growth, reducing nutrient uptake and translocation, including that of $\mathrm{K}^{+}$[48]. Because $\mathrm{Na}^{+}$ions contend with $\mathrm{K}^{+}$for the main binding positions (i.e., low- and high-affinity transporters) through metabolism in the cytoplasm, plant metabolism is disturbed [48,52]. In this work, the application of $\mathrm{K}_{2} \mathrm{SO}_{4}$ as SS or foliar application (FS) under saline soils significantly reduced the contents of $\mathrm{Na}^{+}$and $\mathrm{Cl}^{-}$and enhanced $\mathrm{K}^{+}$content, increasing the ratio of $\mathrm{K}^{+} / \mathrm{Na}^{+}$in stressed soybean plants (Table 2). The transport (high-affinity) of $\mathrm{K}^{+}$mediates the specific transport of $\mathrm{Na}^{+}$or co-transport of $\mathrm{Na}^{+}-\mathrm{K}^{+}$, which plays a crucial role in the ability of plants to tolerate $\mathrm{Na}^{+}$[54]. Potassium application stimulates organic osmolyte synthesis, which is required for fast cell recovery under salinity stress and is organized by higher $\mathrm{K}^{+}$accumulation and lower $\mathrm{Cl}^{-}$and $\mathrm{Na}^{+}$accumulation in cells of the root epidermal, as previously demonstrated in Arabidopsis thaliana [55]. In this manner, excess $\mathrm{Na}^{+}$ levels can be harmful to cell metabolism, and it is critical to preserve cytosolic $\mathrm{K}^{+}$content at a steady (high) rate to maintain plant metabolism [56,57]. A stable $\mathrm{K}^{+}$level in cytosolic is because of consuming of vacuolar $\mathrm{K}^{+}$in $\mathrm{K}^{+}$- lacking situations [48]. Fayez and Bazaid [58] noted that the ratio of $\mathrm{Na}^{+} / \mathrm{K}^{+}$ in Hordeum vulgare was increased due to salinity but reduced under the application of potassium. Additionally, Chakraborty et al. [59] reported that potassium applications may decreased $\mathrm{Na}+$ uptake by organizing the ionic balance in peanut plants. 
Table 2. Changes (\%) in plant growth, physiology, biochemistry and productivity, relative to the control in soybean plants under normal $\left(\mathrm{EC}=2.68 \mathrm{dS} \mathrm{m}^{-1}\right)$ and saline $\left(\mathrm{EC}=7.46 \mathrm{dS} \mathrm{m}^{-1}\right)$ conditions. Three-color scale heatmap: yellow as the midpoint of control and parameters with insignificant values compared to control, red for changes below control values and green for changes over control values.

\begin{tabular}{|c|c|c|c|c|c|c|}
\hline \multirow[b]{2}{*}{ Parameters } & \multirow{2}{*}{$\begin{array}{c}\text { Normal (N) } \\
\text { (Control) }\end{array}$} & \multicolumn{5}{|c|}{ Treatments } \\
\hline & & $\begin{array}{c}\mathrm{N}+ \\
\mathrm{K}(\mathrm{SS})\end{array}$ & $\begin{array}{c}\mathrm{N}+ \\
\mathrm{K}(\mathrm{FS})\end{array}$ & $\begin{array}{l}\text { Salinity } \\
\text { (S) }\end{array}$ & $\begin{array}{c}\text { S+ } \\
\text { K(SS) }\end{array}$ & $\begin{array}{c}\text { S+ } \\
\text { K (FS) }\end{array}$ \\
\hline Shoot length & $a$ & $-1.9 \mathrm{a}$ & $+2.2 \mathrm{a}$ & $-36.1 d$ & $-23.8 c$ & $-10.6 b$ \\
\hline Number of leaves plant ${ }^{-1}$ & $a b$ & $-5.5 b$ & $+5.5 \mathrm{a}$ & $-44.1 d$ & $-29.4 c$ & $-15.1 b$ \\
\hline Leaves area plant ${ }^{-1}$ & $\mathrm{ab}$ & $-19.8 \mathrm{ab}$ & $+7.2 \mathrm{a}$ & $-49.7 d$ & $-27.0 c$ & $-12.7 \mathrm{~b}$ \\
\hline Shoot dry weight & $\mathrm{b}$ & $-4.5 b$ & $+10.1 \mathrm{a}$ & $-43.3 e$ & $-18.0 \mathrm{~d}$ & $-11.2 \mathrm{c}$ \\
\hline Total chlorophylls content & $\mathrm{b}$ & $-3.4 b$ & $+15.3 \mathrm{a}$ & $-69.9 e$ & $-29.7 d$ & $-14.4 \mathrm{c}$ \\
\hline Total carotenoids content & a & $-1.5 \mathrm{a}$ & $+3.0 \mathrm{a}$ & $-25.4 c$ & $-13.4 b$ & $-10.4 b$ \\
\hline Performance index & $\mathrm{ab}$ & $-3.2 \mathrm{ab}$ & $+4.8 \mathrm{a}$ & $-35.5 \mathrm{~d}$ & $-15.7 c$ & $-7.2 b$ \\
\hline Potassium $\left(\mathrm{K}^{+}\right)$content & a & $-9.9 b$ & $0.0 \mathrm{a}$ & $-43.7 d$ & $-28.6 c$ & $-17.1 b$ \\
\hline Sodium $\left(\mathrm{Na}^{+}\right)$content & d & $-8.3 \mathrm{de}$ & $-15.0 \mathrm{e}$ & $+286.7 a$ & $+43.3 b$ & $+21.7 \mathrm{c}$ \\
\hline Chlorine $\left(\mathrm{Cl}^{-}\right)$content & $\mathrm{d}$ & $+1.1 \mathrm{~d}$ & $-5.7 d$ & $+173.6 \mathrm{a}$ & $+31.0 \mathrm{~b}$ & $+12.6 \mathrm{c}$ \\
\hline $\mathrm{K}^{+} / \mathrm{Na}^{+}$ratio & $\mathrm{b}$ & $-1.9 b$ & $+17.6 \mathrm{a}$ & $-85.2 e$ & $-50.0 \mathrm{~d}$ & $-31.9 c$ \\
\hline Free proline content & $\mathrm{b}$ & $-0.7 b$ & $+1.7 \mathrm{~b}$ & $+61.7 a$ & $+60.4 a$ & $+62.4 \mathrm{a}$ \\
\hline Soluble sugars content & c & $-6.1 c$ & $+0.7 \mathrm{c}$ & $+60.8 b$ & $+58.1 \mathrm{~b}$ & $+91.9 \mathrm{a}$ \\
\hline Ascorbate (AsA) content & c & $-8.5 c$ & $+4.2 \mathrm{c}$ & $+100.0 \mathrm{~b}$ & $+102.8 \mathrm{~b}$ & $+129.6 \mathrm{a}$ \\
\hline Glutathione (GSH) content & c & $-4.3 c$ & $-0.9 c$ & $+111.3 \mathrm{~b}$ & $+120.9 \mathrm{~b}$ & $+157.4 \mathrm{a}$ \\
\hline$\alpha$-Tocopherol content & $\mathrm{d}$ & $-2.4 \mathrm{~d}$ & $+2.4 \mathrm{~d}$ & $+107.3 c$ & $+137.4 \mathrm{~b}$ & $+156.1 \mathrm{a}$ \\
\hline Malondialdehyde level & de & $+2.4 \mathrm{de}$ & $-10.8 \mathrm{e}$ & $+126.5 \mathrm{a}$ & $+30.1 \mathrm{~b}$ & $+14.5 \mathrm{c}$ \\
\hline Hydrogen peroxide level & $\mathrm{d}$ & $+0.7 \mathrm{~d}$ & $-1.6 \mathrm{~d}$ & $+187.1 \mathrm{a}$ & $+56.8 \mathrm{~b}$ & $+23.5 c$ \\
\hline SOD activity & $d$ & $-1.1 d$ & $+4.3 \mathrm{~d}$ & $+81.6 \mathrm{c}$ & $+101.4 \mathrm{~b}$ & $+121.3 \mathrm{a}$ \\
\hline CAT activity & c & $+0.5 c$ & $+1.4 \mathrm{c}$ & $-36.2 d$ & $+36.2 \mathrm{~b}$ & $+55.1 \mathrm{a}$ \\
\hline APX activity & c & $+2.6 \mathrm{c}$ & $+3.9 \mathrm{c}$ & $+40.8 b$ & $+44.1 \mathrm{~b}$ & $+65.8 \mathrm{a}$ \\
\hline GPX activity & c & $+1.7 \mathrm{c}$ & $+1.7 \mathrm{c}$ & $+76.4 \mathrm{~b}$ & $+76.0 \mathrm{~b}$ & $+100.8 \mathrm{a}$ \\
\hline Number of pods plant ${ }^{-1}$ & $\mathrm{~b}$ & $-7.0 c$ & $+7.0 \mathrm{a}$ & $-58.1 \mathrm{e}$ & $-33.7 \mathrm{~d}$ & $-12.2 c$ \\
\hline 100-seed weight & a & $-4.4 \mathrm{ab}$ & $+2.2 \mathrm{a}$ & $-60.3 d$ & $-17.6 c$ & $-7.4 \mathrm{~b}$ \\
\hline Seed yield & a & $-6.9 b$ & $+6.9 a$ & $-55.2 d$ & $-24.1 c$ & $-13.8 b$ \\
\hline Protein content (\%) & a & $-1.2 \mathrm{a}$ & $+0.9 \mathrm{a}$ & $-44.2 \mathrm{~d}$ & $-20.9 c$ & $-8.9 b$ \\
\hline Oil content $(\%)$ & a & $-2.6 a$ & $+0.4 \mathrm{a}$ & $-37.7 c$ & $-14.0 \mathrm{~b}$ & $-0.9 a$ \\
\hline
\end{tabular}

Means followed by the same letter in each row are not significantly different according to the LSD test $(p \leq 0.05)$.

In this study, potassium application enhanced organic compounds, such as TSS, proline and AsA (Figure 4). Saneoka et al. [60] reported a close connection between organic compound synthesis and salinity tolerance. Compatible compounds, such as free proline and TSS, preserve the osmotic balance between the vacuole and the cytoplasm. Moreover, they protect physiological processes against harmful inorganic compounds [61,62]. In addition, TSS and proline are considered efficient means of preserving the potential of a passive osmotic process in the cytoplasm and in maintaining ribosomes and proteins against the harmful impacts from $\mathrm{Na}^{+}$ions. The action efficiency of $\mathrm{Na}^{+}$pumps is important to enhancing the role of the organic compounds, which may not be sufficient to confer tolerance to salt stress. Salt stress prompts excessive productions of ROS, resulting in oxidization of some compounds, such as proteins, lipids, carbohydrates and nucleic acid [63].

Excessive levels of ROS in plants grown in salt soils can damage membranes, which are composed primarily of proteins and lipids [64]. ROS can induce peroxidation of lipids (measured in MDA), producing aldehydes, of which MDA is a major type. MDA consequently acts as an indicator of membrane damage from ROS [63]. In our study, the application of potassium reduced excess oxidation of lipids (MDA, Figure 5). This can be attributed to excessive levels of ROS-hunting molecules, such as proline and antioxidants, that restrict peroxidation of lipid-accompanied damage to cell membranes exposed to oxidative stress $[65,66]$.

Plants have a system of antioxidant protection that shields them against oxidative harm. These antioxidants include SOD, APX and CAT. Catalase, doing through a well-defined glutathione-ascorbate pathway $[67,68]$. SOD is considered a first line of defense, catalyzing the dismutation of superoxide 
ions to $\mathrm{H}_{2} \mathrm{O}_{2}$. In the aforementioned results, the application of potassium enhanced antioxidant enzyme activities of SOD, CAT, APX and GPX as well as AsA and $\alpha$-TOC under both normal and saline soil conditions, with decreased ROS formation in plant cells (Figures 4 and 6). These antioxidants are implicated in plant regulation of $\mathrm{H}_{2} \mathrm{O}_{2}$ levels in cells. Liang et al. [69] noted that potassium application increased antioxidant enzyme efficiency of CAT, peroxidase and SOD in zinger plants (Zingiber officinale Roscoe), decreasing ROS synthesis in plant cells. Zheng et al. [70] proposed that applying $\mathrm{KNO}_{3}$ at appropriate amounts can detoxify ROS by enhanced activity of CAR, SOD and peroxidase in Triticum aestivum under salt stress. Jan et al. [71] reported that APX, CAT and SOD activities increased after application of potassium under salt stress and, consequently, detoxified ROS. Application of potassium by both methods (FS and SS) under different soil conditions lowered the inhibitory effect of salinity and improved growth traits that were accompanied by increased yield and its components and seed contents of oil and protein (Figures 1,2,7 and 8). Potassium is reportedly responsible for increasing crop yields due to its positive influence on plant growth under saline environments and the construction of proteins vital to inducing stress tolerance in plants. FS of potassium was more influential in increasing plant performance under salt stress compared with SS, possibly due to supplementation of potassium, as FS offers plants more chances to use the penetrated potassium through leaf stomata in many important processes during the growth stage, particularly photosynthetic traits for extended periods, while potassium taken by seeds through soaking makes potassium unavailable for comparable long periods, only inducing germination to push for strong seedlings under stress.

The improvements observed by $\mathrm{K}$ application, especially when applied as foliar spray (FS), for salt-stressed soybean plant growth and seed and oil yield productions (Figures 1 and 7 , and Table 2) were awarded through its contribution to enhancements in photosynthetic efficiency (Figure 2 and Table 2), $\mathrm{K}^{+}$content and $\mathrm{K}^{+} / \mathrm{Na}^{+}$ratio (Figure 4 and Table 2 ), osmoregulation and antioxidative defense system (Figures 4-6 and Table 2) and suppressions in $\mathrm{Na}^{+}$and $\mathrm{Cl}^{-}$contents (Figure 3 and Table 2) and MDA and $\mathrm{H}_{2} \mathrm{O}_{2}$ levels (Figure 5 and Table 2).

\section{Conclusions}

Physio-biochemical attributes (i.e., total chlorophyll, carotenoids, $\mathrm{K}^{+} / \mathrm{Na}^{+}$ratios and catalase activity), growth traits (i.e., shoot length and dry weight), yield traits (i.e., number of pods plant ${ }^{-1}$ and seed yield $\mathrm{ha}^{-1}$ ) and seed quality (i.e., protein and oil \%) of soybean plants grown in actual saline soil $\left(\mathrm{EC}=7.46 \mathrm{dS} \mathrm{m}^{-1}\right)$ were significantly decreased in comparison to those grown in normal soil $\left(\mathrm{EC}=2.68 \mathrm{dS} \mathrm{m}^{-1}\right)$. In contrast, enzymatic antioxidant activity and non-enzymatic antioxidant contents as well as $\mathrm{Na}^{+}, \mathrm{H}_{2} \mathrm{O}_{2}$ and malondialdehyde were increased in soybean plants grown in saline soil compared with normal soil. However, foliar application of potassium in saline soil (EC, $7.46 \mathrm{dS}$ $\mathrm{m}^{-1}$ ) improved plant-stress defense responses in direct and indirect manners compared with seed soaking treatment and untreated plants. For example, the superior treatment of foliar potassium application increased the content of AsA by $14.79 \%$ and activity of SOD by $21.87 \%$ and CAT by $143.07 \%$, while decreasing MDA content by $49.47 \%$ compared with the control in saline soil. Furthermore, foliar potassium application increased seed yield $\mathrm{ha}^{-1}$ by $92.31 \%$ and protein content by $63.19 \%$ compared with the control under the salt stress condition. In conclusion, exogenous application of $\mathrm{K}_{2} \mathrm{SO}_{4}$ was more effective than seed soaking and proved to be a sustainable option to improve crop yield and seed quality as well as to alleviate salt stress for soybean plants grown in actual saline fields.

Author Contributions: Conceptualization, R.S.T., M.F.S., M.M.R., A.H.A.M., M.A. and B.A.A.; Data curation, R.S.T., M.F.S., M.M.R., A.H.A.M and B.A.A.; Formal analysis, R.S.T., M.F.S., M.M.R., A.H.A.M. and M.A.; Investigation, R.S.T., M.F.S., M.M.R. and A.H.A.M.; Methodology, R.S.T., M.F.S., M.M.R., and A.H.A.M.; Resources, R.S.T., M.F.S., M.M.R., A.H.A.M. and B.A.A.; Software, R.S.T., M.F.S., M.M.R., A.H.A.M., and M.A.; Writing-original draft, R.S.T, M.F.S., M.M.R., A.H.A.M., M.A. and B.A.A.; Writing-review and editing, R.S.T., M.F.S., M.M.R., A.H.A.M. All authors have read and agreed to the published version of the manuscript.

Funding: The Deanship of Scientific Research at King Saud University through the research group number RG-1441-323 is acknowledged. 
Acknowledgments: The Deanship of Scientific Research at King Saud University through RG-1441-323 is acknowledged. The Researchers Support and Services Unit (RSSU) is acknowledged for technical support in terms of language editing.

Conflicts of Interest: The authors declare no conflict of interest.

\section{References}

1. Essa, T.; Al-Ani, D. Effect of salt stress on the performance of six soybean genotypes. Pak. J. Biol. Sci. 2001, 4, 175-177.

2. Agarwal, A.K. Biofuels (alcohols and biodiesel) applications as fuels for internal combustion engines. Prog. Energy Combust. Sci. 2007, 33, 233-271. [CrossRef]

3. Shi, G.; Cai, Q. Zinc tolerance and accumulation in eight oil crops. J. Plant Nutr. 2010, 33, 982-997. [CrossRef]

4. Krishnan, H.B. Biochemistry and molecular biology of soybean seed storage proteins. J. New Seeds 2001, 2, 1-25. [CrossRef]

5. Anonymous. Agricultural Statistics of Pakistan; Ministry of Food, Agriculture and Live Stock, (Economic Wing): Islamabad, Pakistan, 2009; pp. 65-66.

6. FAOSTAT. Food and Agriculture Organization of the United Nations Statistics Division. 2020. Available online: http://faostat.fao.org/site/567/DesktopDefault.aspx (accessed on 20 September 2020).

7. Seleiman, M.F.; Kheir, A.S. Saline soil properties, quality and productivity of wheat grown with bagasse ash and thiourea in different climatic zones. Chemosphere 2018, 193, 538-546. [CrossRef] [PubMed]

8. Ding, Z.; Kheir, A.S.; Ali, O.A.; Hafez, E.; Elshamey, E.A.; Zhou, Z.; Wang, B.; Lin, X.; Ge, Y.; Fahmy, A.E.; et al. A vermicompost and deep tillage system to improve saline-sodic soil quality and wheat productivity. J. Environ. Manag. 2020, 277, 111388. [CrossRef] [PubMed]

9. Nadeem, M.; Li, J.; Yahya, M.; Wang, M.; Ali, A.; Cheng, A.; Wang, X.; Ma, C. Grain legumes and fear of salt stress: Focus on mechanisms and management strategies. Int. J. Mol. Sci. 2019, 20, 799. [CrossRef] [PubMed]

10. Rady, M.M.; Taha, R.S.; Mahdi, A.H.A. Proline enhances growth, productivity and anatomy of two varieties of Lupinus termis L. grown under salt stress. S. Afr. J. Bot. 2016, 102, 221-227. [CrossRef]

11. Jha, U.C.; Bohra, A.; Jha, R.; Parida, S.K. Salinity stress response and 'omics' approaches for improving salinity stress tolerance in major grain legumes. Plant Cell Rep. 2019, 38, 255-277. [CrossRef] [PubMed]

12. Bewley, J.D.; Black, M. Seeds: Physiology of Development and Germination; Plenum Press: New York, NY, USA, 1994.

13. Mcdonald, M.B. Seed priming. In Seed Technology and Its Biological Basis; Black, M., Bewley, J.D., Eds.; Sheffield Academic Press: Sheffield, UK, 2000; pp. 287-325.

14. Soeda, Y.; Konings, M.C.; Vorst, O.; van Houwelingen, A.M.; Stoopen, G.M.; Maliepaard, C.A.; Kodde, J.; Bino, R.J.; Groot, S.P.; van der Geest, A.H. Gene expression programs during Brassica oleracea seed maturation, osmopriming, and germination are indicators of progression of the germination process and the stress tolerance level. Plant Physiol. 2005, 137, 354-368. [CrossRef]

15. El-Lethy, S.R.; Abdelhamid, M.T.; Reda, F. Effect of potassium application on wheat (Triticum aestivum L.) cultivars grown under salinity stress. World Appl. Sci. J. 2013, 26, 840-850.

16. Seleiman, M.F. Use of plant nutrients in improving abiotic stress tolerance in wheat. In Wheat Production in Changing Environments: Management, Adaptation and Tolerance; Hasanuzzaman, M., Nahar, K., Hossain, A., Eds.; Springer Nature: Singapore, 2019; pp. 481-495. ISBN 978-981-13-6883-7. [CrossRef]

17. Xu, X.; Du, X.; Wang, F.; Sha, J.; Chen, Q.; Tian, G.; Zhu, Z.; Ge, S.; Jiang, Y. Effects of Potassium Levels on Plant Growth, Accumulation and Distribution of Carbon, and Nitrate Metabolism in Apple Dwarf Rootstock Seedlings. Front. Plant Sci. 2020, 11. [CrossRef] [PubMed]

18. Waraich, E.A.; Ahmad, R.; Halim, A.; Aziz, T. Alleviation of temperature stress by nutrient management in crop plants: A review. J. Soil Sci. Plant Nutr. 2012, 12, 221-244. [CrossRef]

19. Anaraki, Z.; Shariati, M.; Hosseini Tafreshi, S. Transient silencing of phytoene desaturase reveals critical roles on plant response to salinity stress. Acta Physiol. Plant. 2017, 39, 161. [CrossRef]

20. Clark, A.J.; Landolt, W.; Bucher, J.B.; Strasser, R.J. Beech (Fagus sylvatica) response to ozone exposure assessed with a chlorophyll a fluorescence performance index. Environ. Pollut. 2000, 109, 501-507. [CrossRef]

21. Malavolta, E.; Vitti, G.C.; Oliveira, S.A. Avaliação do Estudonutricional das Plantas, Princípios e Aplicações; POTAFOS: Piracicaba, Brazil, 1989; 97p. 
22. Gaines, T.P.; Parker, M.B.; Gascho, G.J. Automated determination of chlorides in soil and plant tissue by sodium nitrate Extraction 1. Agron. J. 1984, 76, 371-374. [CrossRef]

23. Sofy, M.R.; Seleiman, M.F.; Alhammad, B.A.; Alharbi, B.M.; Mohamed, H.I. Minimizing Adverse Effects of Pb on Maize Plants by Combined Treatment with Jasmonic, Salicylic Acids and Proline. Agronomy 2020, 10, 699. [CrossRef]

24. Irigoyen, J.J.; Emerich, D.W.; Sanchez-Diaz, M. Water stress induced changes in the concentrations of proline and total soluble sugars in nodulated alfalfa (Medicago sativa) plants. Physiol. Plant. 1992, 8, 455-460. [CrossRef]

25. Mukherjee, S.P.; Choudhuri, M.A. Implications of water stress induced changes in the levels of endogenous ascorbic acid and hydrogen peroxide in Vigna seedlings. Physiol. Plant. 1983, 58, 166-170. [CrossRef]

26. Griffith, O.W. Determination of glutathione and glutathione disulfide using glutathione reductase and 2 vinylpyridine. Anal. Biochem. 1980, 106, 207-212. [CrossRef]

27. Konings, E.J.M.; Roomans, H.H.S.; Beljaars, P.R. Liquid chromatographic determination of tocopherols and tocotrienols in margarine, infant foods, and vegetables. J. AOAC Int. 1996, 79, 902-906. [CrossRef]

28. Ching, L.S.; Mohamed, S. Alpha-tocopherol content in 62 edible tropical plants. J. Agric. Food Chem. 2001, 49, 3101-3105. [CrossRef]

29. MadhavaRao, K.V.; Sresty, T.V.S. Antioxidative parameters in the seedlings of pigeonpea (Cajanuscajan L. Millspaugh) in response to Zn and Ni stresses. Plant Sci. 2000, 157, 113-128. [CrossRef]

30. Bradford, M.M. A rapid and sensitive method for the quantitation of microgram quantities of protein utilizing the principle of protein-dye binding. Anal. Biochem. 1976, 72, 248-254. [CrossRef]

31. Beauchamp, C.; Fridovich, I. Superoxide dismutase: Improved assays and an assay applicable to acrylamide gels. Anal. Biochem. 1971, 44, 276-287. [CrossRef]

32. Havir, E.A.; McHale, N.A. Biochemical and developmental characterization of multiple forms of catalase in tobacco leaves. Plant Physiol. 1987, 84, 450-455. [CrossRef]

33. Nakano, Y.; Asada, K. Hydrogen peroxide is scavenged by ascorbate specific peroxidase in spinach chloroplasts. Plant Cell Physiol. 1981, 22, 867-868.

34. Kar, M.; Mishra, D. Catalase, peroxidase, and polyphenoloxidase activities during rice leaf senescence. Plant Physiol. 1976, 57, 315-319. [CrossRef]

35. AOAC. Official Methods of Analysis of Association of Official Agricultural Chemists, 18th ed.; The Association of Official Analytical Chemists: Washington, DC, USA, 2010.

36. Gomez, K.A.; Gomez, A.A. Statistical Procedures for Agricultural Research, 2nd ed.; John Wiley \& Sons: Singapore, 1984; p. 680.

37. Semida, W.M.; Taha, R.S.; Abdelhamid, M.T.; Rady, M.M. Foliar-applied $\alpha$-tocopherol enhances salt-tolerance in Vicia faba L. plants grown under saline conditions. S. Afr. J. Bot. 2014, 95, 24-31. [CrossRef]

38. Mahdi, A.H.A. Improvement of salt tolerance in Vicia faba (L.) Plants by exogenous application of polyamines. Egypt. J. Agron. 2016, 38, 1-21.

39. Taha, R.S. Improving Salt Tolerance of Helianthus annuus (L.) Plants by Moringa oleifera Leaf extract. Egypt. J. Agron. 2016, 38, 117-140.

40. Hasanuzzaman, M.; Nahar, K.; Gil, S.S.; Fujita, M. Drought stress responses in plants, oxidative stress and antioxidant defense. In Climate Change and Plant Abiotic Stress Tolerance; Gill, S.S., Tuteja, N., Eds.; Wiley: Weinheim, Germany, 2014; pp. 209-249.

41. Hameed, A.; Goher, M.; Iqbal, N. Drought induced programmed cell death and associated changes in antioxidants, proteases, and lipid peroxidation in wheat leaves. Biologia Plant. 2013, 57, 370-374. [CrossRef]

42. Abd El-Mageed, T.A.; Semida, W.M.; Taha, R.S.; Rady, M.M. Effect of summer-fall deficit irrigation on morpho-physiological, anatomical responses, fruit yield and water use efficiency of cucumber under salt affected soil. Sci. Hortic. 2018, 237, 148-155. [CrossRef]

43. Foyer, C.H.; Noctor, G. Oxygen processing in photosynthesis: Regulation and signalling. New Phytol. 2000, 146, 359-388. [CrossRef]

44. Wang, H.; Liu, J.; Wu, L. Methylglyoxal-induced mitochondrial dysfunction in vascular smooth muscle cells. Biochem. Pharmacol. 2009, 77, 1709-1716. [CrossRef]

45. Desai, K.M.; Chang, T.; Wang, H.; Banigesh, A.; Dhar, A.; Liu, J.; Untereiner, A.; Wu, L. Oxidative stress and aging: Is methylglyoxal the hidden enemy? Can. J. Physiol. Pharmacol. 2010, 88, 273-284. [CrossRef] [PubMed] 
46. Taha, R.S.; Alharby, H.F.; Bamagoos, A.A.; Medani, R.A.; Rady, M.M. Elevating tolerance of drought stress in Ocimum basilicum using pollen grains extract; a natural biostimulant by regulation of plant performance and antioxidant defense system. S. Afr. J. Bot. 2020, 128, 42-53. [CrossRef]

47. Hernández, J.A.; Jiménez, A.; Mullineaux, P.; Sevilia, F. Tolerance of pea (Pisum sativum L.) to long-term salt stress is associated with induction of antioxidant defences. Plant Cell Environ. 2000, 23, 853-862. [CrossRef]

48. Wang, M.; Zheng, Q.; Shen, Q.; Guo, S. The critical role of potassium in plant stress response. Int. J. Mol. Sci. 2013, 14, 7370-7390. [CrossRef]

49. Ling, F.; Silberbush, M. Response of maize to foliar vs. soil application of nitrogen-phosphorus-potassium fertilizers. J. Plant Nutr. 2002, 25, 2333-2342. [CrossRef]

50. Pettigrew, W.T. Potassium influences on yield and quality production for maize, wheat, soybean and cotton. Physiol. Plant. 2008, 133, 670-681. [CrossRef]

51. Zörb, C.; Senbayram, M.; Peiter, E. Potassium in agriculture-Status and perspectives. J. Plant Physiol. 2014, 171, 656-669. [CrossRef]

52. Marschner, H. Marschner's Mineral Nutrition of Higher Plants, 3rd ed.; Academic Press: London, UK, 2012; pp. 178-189.

53. Shingles, R.; McCarty, R.E. Direct measurement of ATP-dependent proton concentration changes and characterization of a K-stimulated ATPase in pea chloroplast inner envelope vesicles. Plant Physiol. 1994, 106, 731-737. [CrossRef] [PubMed]

54. Su, Y.; Luo, W.; Lin, W.; Ma, L.; Kabir, M.H. Model of cation transportation mediated by high-affinity potassium transporters (HKTs) in higher plants. Biol. Proced. Online 2015, 17, 1-13. [CrossRef]

55. Shabala, S.N.; Lew, R.R. Turgor regulation in osmotically stressed Arabidopsis epidermal root cells. Direct support for the role of inorganic ion uptake as revealed by concurrent flux and cell turgor measurements. Plant Physiol. 2002, 129, 290-299. [CrossRef]

56. Flowers, T.J.; Munns, R.; Colmer, T.D. Sodium chloride toxicity and the cellular basis of salt tolerance in halophytes. Ann. Bot. 2015, 115, 419-431. [CrossRef] [PubMed]

57. Shabala, L.; Zhang, J.; Pottosin, I.; Bose, J.; Zhu, M.; Fuglsang, A.T.; Velarde-Buendia, A.; Massart, A.; Hill, C.B.; Roessner, U.; et al. Cell-type specific H+-ATPase activity in root tissues enables K+ retention and mediates acclimation of barley (Hordeum vulgare L.) to salinity stress. Plant Physiol. 2016, 172, 2445-2458. [CrossRef]

58. Fayez, K.A.; Bazaid, S.A. Improving drought and salinity tolerance in barley by application of salicylic acid and potassium nitrate. J. Saudi Soc. Agric. Sci. 2014, 13, 45-55. [CrossRef]

59. Chakraborty, K.; Bhaduri, D.; Meena, H.N.; Kalariya, K. External potassium $\left(\mathrm{K}^{+}\right)$application improves salinity tolerance by promoting $\mathrm{Na}^{+}$-exclusion, $\mathrm{K}^{+}$-accumulation and osmotic adjustment in contrasting peanut cultivars. Plant Physiol. Biochem. 2016, 103, 143-153. [CrossRef]

60. Saneoka, H.; Nagasaka, C.; Hahn, D.T.; Yang, W.J.; Premachandra, G.S.; Joly, R.J.; Rhodes, D. Salt tolerance of glycinebetaine-defcient and -containing maize lines. Plant Physiol. 1995, 107, 631-638. [CrossRef]

61. Shomer, I.; Frenkel, H.; Polinger, C. The existence of a diffuse electric double layer at cellulose fbril surfaces and its role in the swelling mechanism of parenchyma plant cell walls. Carbohydr. Polym. 1991, 16, 199-210. [CrossRef]

62. Rady, M.M.; Taha, R.S.; Semida, W.M.; Alharby, H.F. Modulation of salt stress effects on Vicia faba L. plants grown on a reclaimed-saline soil by salicylic acid application. Rom. Agric. Res. 2017, 34, 175-185.

63. Anjum, N.A.; Aref, I.M.; Duarte, A.C.; Pereira, E.; Ahmad, I.; Iqbal, M. Glutathione and proline can coordinately make plants withstand the joint attack of metal (loid) and salinity stresses. Front. Plant Sci. 2014, 5, 662. [CrossRef]

64. Iqbal, M.; Ahmad, A.; Ansari, M.K.A.; Qureshi, M.I.; Aref, I.M.; Khan, P.R.; Hegazy, S.S.; El-Atta, H.; Husen, A.; Hakeem, K.R. Improving the phytoextraction capacity of plants to scavenge metal (loid)-contaminated sites. Environ. Rev. 2015, 23, 44-65. [CrossRef]

65. Khan, M.N.; Siddiqui, M.H.; Mohammad, F.; Khan, M.M.A.; Naeem, M. Salinity induced changes in growth, enzyme activities, photosynthesis, proline accumulation and yield in linseed genotypes. World J. Agric. Sci. 2007, 3, 685-695.

66. Qureshi, M.I.; Abdin, M.Z.; Ahmad, J.; Iqbal, M. Effect of long-term salinity on cellular antioxidants, compatible solute and fatty acid profile of Sweet annie (Artemisia annua L.). Phytochemistry 2013, 95, $215-223$. [CrossRef] 
67. Anjum, N.A.; Ahmad, I.; Mohmood, I.; Pacheco, M.; Duarte, A.C.; Pereira, E.; Umar, S.; Ahmad, A.; Khan, N.A.; Iqbal, M.; et al. Modulation of glutathione and its related enzymes in plants' responses to toxic metals and metalloids-a review. Environ. Exp. Bot. 2011, 75, 307-324. [CrossRef]

68. Anjum, N.A.; Sofo, A.; Scopa, A.; Roychoudhury, A.; Gill, S.S.; Iqbal, M.; Lukatkin, A.S.; Pereira, E.; Duarte, A.C.; Ahmad, I. Lipids and proteins-major targets of oxidative modifications in abiotic stressed plants. Environ. Sci. Pollut. Res. 2015, 22, 4099-4121. [CrossRef]

69. Liang, T.B.; Wang, Z.L.; Wang, R.J.; Liu, L.L.; Shi, C.Y. Effects of potassium humate on ginger root growth and its active oxygen metabolism. Ying Yong Sheng Tai Xue Bao J. Appl. Ecol. 2007, 18, 813-817.

70. Zheng, Y.; Jia, A.; Ning, T.; Xu, J.; Li, Z.; Jiang, G. Potassium nitrate application alleviates sodium chloride stress in winter wheat cultivars differing in salt tolerance. J. Plant Physiol. 2008, 165, 1455-1465. [CrossRef]

71. Jan, A.U.; Hadi, F.; Nawaz, M.A.; Rahman, K. Potassium and zinc increase tolerance to salt stress in wheat (Triticum aestivum L.). Plant Physiol. Biochem. 2017, 116, 139-149. [CrossRef]

Publisher's Note: MDPI stays neutral with regard to jurisdictional claims in published maps and institutional affiliations.

(C) 2020 by the authors. Licensee MDPI, Basel, Switzerland. This article is an open access article distributed under the terms and conditions of the Creative Commons Attribution (CC BY) license (http://creativecommons.org/licenses/by/4.0/). 